\title{
ZAPOTRZEBOWANIA KOBIET Z WOJEWÓDZTWA ZACHODNIOPOMORSKIEGO NA USŁUGI OKOŁOPORODOWE ŚWIADCZONE PRZEZ POŁOŻNE ORAZ STOPIEŃ ZNAJOMOŚCI PRZEZ ŚRODOWISKO MEDYCZNE USTAWOWYCH KOMPETENCJI ZAWODOWYCH POLSKICH POLOŻNYCH*
}

\author{
THE SOCIAL DEMAND FOR PERINATAL SERVISES GIVEN BY MIDWIFES \\ AMONG WOMEN FROM ZACHODNIOPOMORSKIE PROVINCE AND \\ INVESTIGATE THE KNOWLEDGE BASE OF MEDICAL STAFF IN REGARD TO \\ THE MIDWIFE'S RIGHTS AND DUTIES RESULTING FROM POLISH LAW*
}

\author{
Samodzielna Pracownia Umiejętności Położniczych Pomorskiego Uniwersytetu Medycznego w Szczecinie \\ ul. Żołnierska 42, 71-210 Szczecin \\ Kierownik: dr n. med. Dorota Ćwiek
}

\begin{abstract}
Summary
Introduction: The midwife's profession has evolved across the ages to become - in the vast majority of countries, including Poland - an independent medical occupation.

The aim of this thesis was to define how big is the social demand for perinatal servises given by midwifes among women from Zachodniopomorskie province and investigate the knowledge base of medical staff in Zachodniopomorskie province in regard to the midwife's rights and duties resulting from Polish law.

Material and methods: Research was carried out from 1.10.2009 to 30.06.2010. It included 115 active midwifes in the city of Szczecin and beyond it (Zachodniopomorskie province). Additionally, 40 doctors, 99 nurses and 1 master of physiotherapy took part in the survey (all of them based in Zachodniopomorskie province). Research was also conducted among 150 women from the same province. The survey was presented in the form of a questionnaire. Since the available literature did not include a standardized research tool which could be used to achieve appointed goals a new method was devised. Results were subjected to mathematical and statistical analysis.

Conclusions: After the compilation of results presented in this paper the following conclusions were made: 1 . Some
\end{abstract}

of the medical personnel who participated in the survey do not perceive midwifes as independent medical practitioners. 2. Most midwifes are aware of their rights and obligations outlined in Polish legislation. In their opinion the lack of independence in their profession is caused by unclear clauses and paragraphs in Polish law. The women who participated in the survey showed an interest in services provided by midwifes. 3 . They stated that there is a common need for this kind of service. There are grounds to intensify the promotion of midwifery as an independent occupation.

K e y w o rds: midwife - competences - law - woman gestation.

\section{Streszczenie}

Wstęp: W ciągu wieków zawód położnej ewoluował, stając się w większości krajów, w tym i w Polsce, samodzielnym zawodem medycznym.

Celem pracy było określenie zapotrzebowania kobiet z województwa zachodniopomorskiego na usługi okołoporodowe świadczone przez położne oraz określenie stopnia znajomości przez środowisko medyczne województwa

* Zwięzła wersja rozprawy doktorskiej przyjętej przez Radę Wydziału Nauk o Zdrowiu Pomorskiego Uniwersytetu Medycznego w Szczecinie. Promotor: prof. dr hab. n. med. Jacek Rudnicki. Oryginalny maszynopis obejmuje: 271 stron, 113 tabel, 53 ryciny, 148 pozycji piśmiennictwa. 
zachodniopomorskiego ustawowych kompetencji zawodowych polskich położnych.

Materiat i metody: Wszystkie badania przeprowadzono 1.10.2009-30.06.2010 r. Objęto nimi 115 aktywnych zawodowo położnych, 40 lekarzy, 99 pielęgniarek oraz 1 magistra fizjoterapii (łącznie 255 osób). Badaniami objęto także 150 kobiet z województwa zachodniopomorskiego. Zastosowano wywiad kwestionariuszowy na podstawie własnego narzędzia badawczego. Uzyskane wyniki poddano analizie matematycznej i statystycznej.

Wnioski: 1. Istnieje potrzeba edukacji środowisk medycznych, włączając w to samo środowisko położnych, na temat ram prawnych zawodu położnej. 2. Należałoby przeprowadzić dogłębną analizę obowiązujących przepisów prawnych, zarówno nadrzędnych w stosunku do ustawodawstwa położnych, jak i tych bezpośrednio dotyczących profesji ze względu na praktykowanie w zawodzie położnej i ze względu na oczekiwania kobiet. 3. Wydaje się zasadnym zintensyfikowanie promocji zawodu położnej.

H a s ła: położna - kompetencje - prawo - kobieta ciąża.

\section{Wstęp}

Zawód położnej jest prawdopodobnie jednym z pierwszych zajęć w społecznościach ludzkich. Łączy w sobie wiedzę, zdolności manualne i kliniczne, a także predyspozycje psychiczne oraz etyczne, niezależne od kultury, szerokości geograficznej czy okresu historycznego $[1,2]$. Od każdego, kto asystował rodzącym kobietom, wymagano doświadczenia, wiedzy i umiejętności współpracy. Osoby te cechować musiała: wspólnota celów, odpowiedzialność, wspólne ustalenie zakresu działań oraz sprawne przekazywanie informacji [3].

Samodzielność i niezależność zawodu położnej nie jest nową ideą. Jej źródeł należy poszukiwać w odległej przeszłości. Sięganie do historii nie jest anachronizmem. Trafnie określił to na przełomie XIX i XX w. redaktor naczelny „Krytyki Lekarskiej” Zygmunt Kramsztyk: ,Jeżeli ktoś chce poznać prawdziwie naukę jako jeden z najważniejszych fenomenów życia ludzkiego, musi uczyć się ją poznawać w ujęciu historycznym" [4].

Wraz z zapoczątkowanymi w 1989 r. przemianami politycznymi, które w 2004 r. zwieńczone zostały przyjęciem Polski do Unii Europejskiej, zmianie ulegała zawodowa sytuacja wielu profesji, w tym również rola i kompetencje zawodowe położnej. Przez wiele lat funkcjonowania poprzedniego ustroju były one systematycznie ograniczane, aby w rezultacie doprowadzić status położnej do zawodu intelektualnie i ustawowo niesamodzielnego, a także podległego [5]. Również społeczeństwo polskie w okresie istnienia Polskiej Rzeczpospolitej Ludowej przestało postrzegać położną jako samodzielnego, w pełni profesjonalnego świadczeniodawcę [6].
Proces zmian w prawie medycznym po włączeniu Polski do krajów Wspólnoty Europejskiej ma coraz większe odzwierciedlenie w podejmowanych uchwałach dotyczących zawodu położnej. Jednakże rzeczywistość ta rozmija się z faktycznymi możliwościami praktykowania w zawodzie w oparciu o aktualne umocowania prawne. Zachodzące procesy przemian zaowocowały także rozbudzeniem dążeń samego środowiska położnych w kierunku samodzielności zawodowej [7, 8]. Współczesne położne, czerpiąc wiedzę $\mathrm{z}$ doświadczeń swoich poprzedników, budują swój aktualny wizerunek, dbają o rozwój zawodowy oraz prestiż profesji, jednocześnie troszcząc się o swoich podopiecznych. Równolegle do tego procesu wzrastało zapotrzebowanie społeczne na usługi położnych [9].

Celem pracy było określenie zapotrzebowania kobiet z województwa zachodniopomorskiego na usługi okołoporodowe świadczone przez położne oraz określenie stopnia znajomości przez środowisko medyczne województwa zachodniopomorskiego ustawowych kompetencji zawodowych polskich położnych.

\section{Material i metody}

Wszystkie badania przeprowadzono w okresie 1.10.200930.06.2010 r. na terenie miasta Szczecina i województwa zachodniopomorskiego. Badaniami objęto 115 aktywnych zawodowo położnych wykonujących zawód w różnych formach. W badaniach wzięło udział także 40 lekarzy, 99 pielęgniarek oraz 1 magister fizjoterapii. Narzędziem pomiaru w stosunku do każdej grupy respondentów był sondaż w formie ankiety własnego autorstwa.

Wypełnienie ankiet zostało zaproponowane również kobietom ciężarnym - uczestniczkom Akademickiej Szkoły Rodzenia „Pomorzanka” mieszczącej się w budynku Pomorskiego Uniwersytetu Medycznego w Szczecinie przy ul. Żołnierskiej 48, uczestniczkom Szkoły Rodzenia im. św. Joanny Beretty Molli przy placu Ofiar Katynia w Szczecinie, jak również pacjentkom 2 prywatnych gabinetów ginekologicznych. Prawidłowo ankiety wypełniło 150 kobiet. Zebrane kwestionariusze zostały zarchiwizowane $\mathrm{w}$ formie elektronicznej, a niezbędnych przekształceń oraz wstępnych wyliczeń dokonano w arkuszu kalkulacyjnym Microsoft Excel 2007. Szczegółowa analiza statystyczna została przeprowadzona z wykorzystaniem programu Statistica 7.1 PL.

\section{Wyniki}

\section{Wiedza kobiet ciężarnych na temat zawodu położnej}

Podstawowe statystyki opisowe dotyczące wieku respondentek przedstawiono w tabeli 1. Połowa ankietowanych pochodziła ze Szczecina (75 osób), druga połowa jako miejsce zamieszkania wskazała inną miejscowość. Większość ankietowanych (98 osób, 65,33\%) ukończyła studia wyższe (tab. 2). Co czwarta kobieta miała wykształcenie średnie 
T a b e l a 1. Podstawowe statystyki opisowe dotyczące wieku respondentek Statystyki opisowe

\begin{tabular}{cccccc}
\hline \multirow{2}{*}{ Wiek } & $\mathrm{n}$ ważnych & średnia & min. & maks. & $\mathrm{SD}$ \\
\cline { 2 - 6 } & 150 & 33,01333 & 16 & 75 & 10,07021 \\
\hline
\end{tabular}

T a b e la 2. Wykształcenie ankietowanych kobiet a ich wiedza na temat samodzielności zawodu położnej

\begin{tabular}{lccc}
\multicolumn{1}{c}{ Wykształcenie } & Tak & Nie & Razem \\
\hline Podstawowe & $3(3,03 \%)$ & $3(5,88 \%)$ & $6(4,00 \%)$ \\
\hline Średnie & $20(20,20 \%)$ & $13(25,49 \%)$ & $33(22,00 \%)$ \\
\hline $\begin{array}{l}\text { Pomaturalne/ } \\
\text { policealne }\end{array}$ & $10(10,10 \%)$ & $3(5,88 \%)$ & $13(8,67 \%)$ \\
\hline Wyższe & $66(66,67 \%)$ & $32(62,75 \%)$ & $98(65,33 \%)$ \\
\hline Ogół & $99(100,00 \%)$ & $51(100,00 \%)$ & $150(100,00 \%)$ \\
\hline
\end{tabular}

$\mathrm{T}$ a b e 1 a 3 . Wykształcenie kobiet a ich wiedza na temat podawania przez położną leków bez zlecenia lekarskiego

\begin{tabular}{lcccc} 
Wykształcenie & Tak & Nie & $\begin{array}{c}\text { Nigdy o tym } \\
\text { nie słyszałam }\end{array}$ & Razem \\
\hline Podstawowe & 0 & 3 & 3 & $6(4,00 \%)$ \\
\hline Średnie & 8 & 12 & 13 & $33(22,00 \%)$ \\
\hline $\begin{array}{l}\text { Pomaturalne/ } \\
\text { policealne }\end{array}$ & 3 & 5 & 5 & $13(8,67 \%)$ \\
\hline Wyższe & 25 & 31 & 42 & $98(65,33 \%)$ \\
\hline Ogół & 36 & 51 & 63 & $150(100,00 \%)$ \\
\hline
\end{tabular}

T a b e la 4. Wyniki testu niezależności między wykształceniem badanych a ich wiedza na temat możliwości prowadzenia i przyjęcia porodu fizjologicznego przez położną

Statystyki:

Parametry poród fizjologiczny (4) $\times$ wykształcenie $(2)$

\begin{tabular}{lccc}
\cline { 2 - 4 } & $\chi^{2}$ & df & $p$ \\
\hline$\chi^{2}$ Pearsona & 11,52634 & 3 & 0,00920 \\
\hline$\chi^{2}$ NW & 10,09350 & 3 & 0,01779 \\
\hline
\end{tabular}

$\mathrm{T}$ a b e 1 a 5 . Kontakt ankietowanych $\mathrm{z}$ położną a ich wiedza na temat samodzielności zawodu położnej

\begin{tabular}{lccc} 
Samodzielność & \multicolumn{3}{c}{ Kontakt z położną } \\
\cline { 2 - 4 } zawodu położnej & tak & nie & razem \\
\hline Nie & $23(25,84 \%)$ & $26(42,62 \%)$ & $49(32,67 \%)$ \\
\hline Tak & $66(74,16 \%)$ & $35(57,38 \%)$ & $101(67,33 \%)$ \\
\hline Ogół & $89(100,00 \%)$ & $61(100,00 \%)$ & $150(100,00 \%)$ \\
\hline
\end{tabular}

T a b e la 6. Wyniki testu niezależności między kontaktem badanych kobiet z położną a ich wiedzą na temat samodzielności zawodu położnej Statystyki:

Parametry $\quad$ samodzielny zawód $(2) \times$ kontakt z położną (2)

\begin{tabular}{lccc} 
& $\chi^{2}$ & $\mathrm{df}$ & $\mathrm{p}$ \\
\hline$\chi^{2}$ Pearsona & 4,633303 & 1 & 0,03136 \\
\hline$\chi^{2} \mathrm{NW}$ & 4,596514 & 1 & 0,03204 \\
\hline
\end{tabular}

(33 osoby, 22\%), pomaturalną szkołę ukończyło 13 badanych $(8,67 \%)$, a 6 miało wykształcenie podstawowe (4\%); $89(59,33 \%)$ kobiet miało do czynienia z grupą zawodową położnych, w przeciwieństwie do 61 (40,67\%) ankietowanych.

Respondentki zapytano o posiadanie dzieci. Więcej niż jedna na cztery ankietowane oczekiwała dziecka (34 osoby, $22,82 \%)$. W badaniu wzięło udział również 28 bezdzietnych kobiet $(18,79 \%)$. Kobiety posiadające potomstwo stanowiły $58,39 \%$ ( 87 osób). Jedna osoba nie udzieliła odpowiedzi na pytanie.

Kobiety biorące udział w sondażu - bez względu na wykształcenie - zazwyczaj nie słyszały o możliwości podawania przez położną leków ważnych dla przebiegu porodu, połogu oraz laktacji bez zlecenia lekarskiego (tab. 3).

Przyjęty poziom istotności pozwala stwierdzić, że wiedza kobiet na temat uprawnień położnej do prowadzenia i przyjęcia porodu fizjologicznego istotnie zależała od wykształcenia $(\mathrm{p}<0,05)$. Możliwość taką znacznie częściej dostrzegały kobiety po studiach wyższych, one też częściej przyznawały się do niewiedzy w tym zakresie. Natomiast osoby po szkole średniej znacznie częściej twierdziły, że nie słyszały o podobnych sytuacjach (tab. 4).

Opinie ankietowanych na temat samodzielności zawodu położnej istotnie zależały od tego, czy kobiety wypełniające kwestionariusze miały wcześniejszy kontakt $\mathrm{z}$ położną $(\mathrm{p}<0,05)$. Wyniki przedstawiono $\mathrm{w}$ tabeli 5 .

Przy przyjętym poziomie istotności zależność między wiedzą kobiet na temat uprawnień położnych do podawania bez zlecenia lekarskiego niektórych bardzo ważnych leków dla przebiegu porodu, połogu i laktacji a wcześniejszym kontaktem ankietowanych z przedstawicielem tego zawodu okazała się statystycznie znacząca $(p<0,05)$. Respondentki, które miały kontakt z położną, istotnie częściej uważały, że położnej przysługują wymienione uprawnienia (tab. 6-10).

Respondentki zapytano o źródła informacji na temat możliwości korzystania z usług położnej. Większość kobiet dowiedziała się tego od koleżanki, z Internetu i ze szkoły rodzenia (ryc. 1).

Kobiety prawie jednogłośnie przyznały, że występuje zapotrzebowanie na świadczenia położnych (136 osób, 90,67\%). Tylko co dziesiąta respondentka wyraziła odmienną opinię (14 osób, 9,33\%). Badanym zadano też pytanie dotyczące ewentualnej możliwości wybrania położnej do prowadzenia porodu. Zdecydowana większość

T a b e 1 a 7. Kontakt badanych kobiet z położną a ich wiedza na temat uprawnień położnej do prowadzenia i przyjęcia porodu fizjologicznego Prowadzenie i przyjęcie Kontakt z położną

\begin{tabular}{lccc}
\multicolumn{1}{c}{$\begin{array}{c}\text { Prowadzenie i przyjęcie } \\
\text { porodu fizjologicznego }\end{array}$} & tak & nontakt z położną & razem \\
\cline { 2 - 4 } & $61(70,93 \%)$ & $21(36,21 \%)$ & $82(56,94 \%)$ \\
\hline Tak & $2(2,33 \%)$ & $12(20,69 \%)$ & $14(9,72 \%)$ \\
\hline Nigdy o tym nie słyszałam & $7(8,14 \%)$ & $11(18,97 \%)$ & $18(12,5 \%)$ \\
\hline Nie wiem & $16(18,60 \%)$ & $14(24,14 \%)$ & $30(20,83 \%)$ \\
\hline Tak, ale tylko w obecności lekarza & $86(100,00 \%)$ & $58(100,00 \%)$ & $144(100,00 \%)$ \\
\hline Ogół & &
\end{tabular}


T a b e 1 a 8 . Wyniki testu niezależności między kontaktem badanych kobiet $\mathrm{z}$ położną a ich wiedzą na temat uprawnień położnej do prowadzenia i przyjęcia porodu fizjologicznego

Statystyki:

\begin{tabular}{lccc}
\multirow{2}{*}{ Parametry } & \multicolumn{4}{c}{ Statystyki: } \\
& poród fizjologiczny $(4) \times$ kontakt z położną (2) \\
\cline { 2 - 4 }$\chi^{2}$ & $\mathrm{df}$ & $\mathrm{p}$ \\
\hline$\chi^{2}$ Pearsona & 23,10645 & 3 & 0,00004 \\
\hline$\chi^{2} \mathrm{NW}$ & 23,84610 & 3 & 0,00003 \\
\hline
\end{tabular}

T a b e 1 a 9. Kontakt badanych kobiet z położną a ich wiedza na temat uprawnienia położnej do podawania leków ważnych dla przebiegu porodu, pologu i laktacji

\begin{tabular}{lccc}
\multirow{2}{*}{ Podanie leków } & \multicolumn{3}{c}{ Kontakt z położną } \\
\cline { 2 - 4 } & tak & nie & razem \\
\hline Tak & $30(33,71 \%)$ & $6(9,84 \%)$ & $36(24,00 \%)$ \\
\hline Nie & $25(28,09 \%)$ & $26(42,62 \%)$ & $51(34,00 \%)$ \\
\hline $\begin{array}{l}\text { Nigdy o tym } \\
\text { nie słyszałam }\end{array}$ & $34(38,20 \%)$ & $29(47,54 \%)$ & $63(42,00 \%)$ \\
\hline Ogół & $89(100,00 \%)$ & $61(100,00 \%)$ & $150(100,00 \%)$ \\
\hline
\end{tabular}

T a b e la 10. Wyniki testu niezależności między kontaktem badanych kobiet $\mathrm{z}$ polożna a ich wiedzą na temat uprawnienia położnej do podawania leków ważnych dla przebiegu porodu, połogu i laktacji Statystyki:

\begin{tabular}{llcc}
\multirow{2}{*}{ Parametry } & \multicolumn{4}{c}{ podanie leków (3) $\times$ kontakt z położną (2) } \\
\cline { 2 - 4 } & $\chi^{2}$ & $\mathrm{df}$ & $\mathrm{p}$ \\
\hline$\chi^{2}$ Pearsona & 11,59374 & 2 & 0,00304 \\
\hline$\chi^{2} \mathrm{NW}$ & 12,62559 & 2 & 0,00181 \\
\hline
\end{tabular}

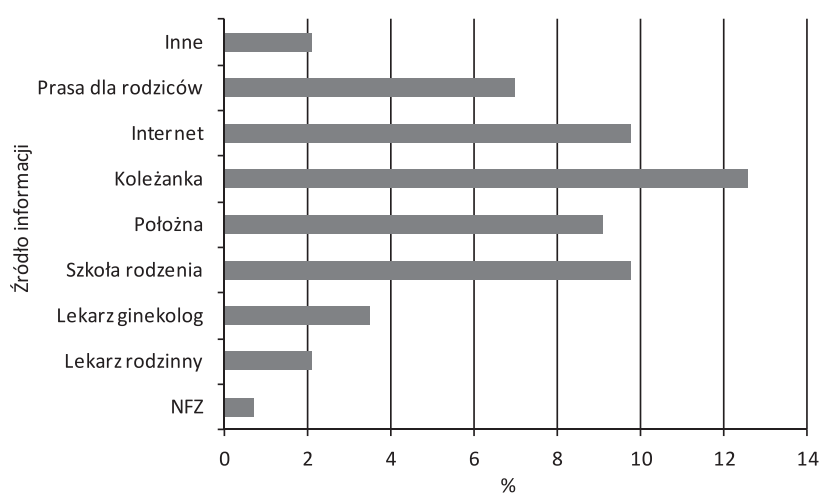

Ryc. 1. Źródło informacji na temat możliwości korzystania z usług położnej

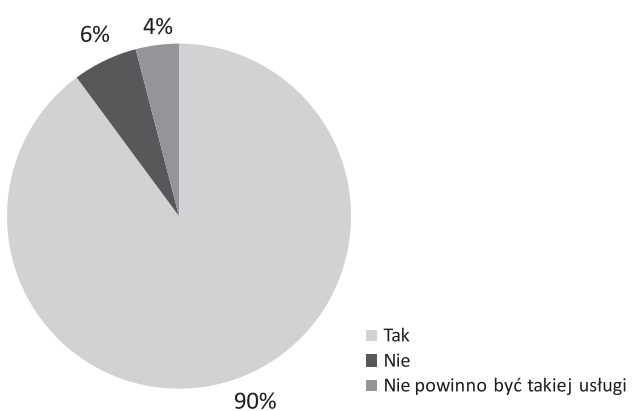

Ryc. 2. Opinia kobiet na temat refundowania przez NFZ porodu prowadzonego przez położną spoza szpitala

badanych odpowiedziała pozytywnie (120 osób, 81,63\% udzielonych odpowiedzi). Argumentowały zazwyczaj tym, iż obecność znajomej położnej podczas porodu działałaby

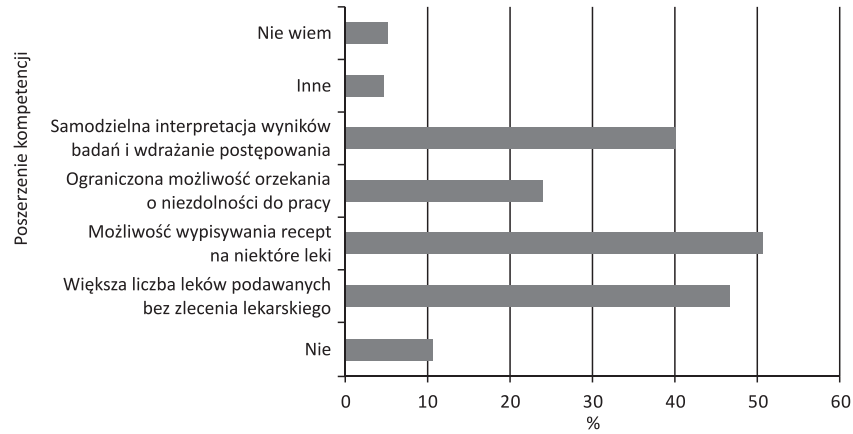

Ryc. 3. Kompetencje, o jakie należałoby poszerzyć zakres uprawnień położnych

na nie uspokajająco. Negatywnie na powyżzze pytanie odpowiedziała niemal co piąta respondentka (27 osób, 18,37\%). Wśród argumentów tej grupy kobiet najczęściej pojawiała się opinia, iż czułyby się bezpieczniej, gdyby podczas porodu był obecny lekarz. Trzy osoby nie udzieliły w ogóle odpowiedzi na powyższe pytanie; $90 \%$ procent odpowiadających uznało także, że usługa powinna być refundowana ze środków publicznych (ryc. 2).

Respondentki zapytano również, o jakie kompetencje powinny być poszerzone uprawnienia położnych. Najczęstszą odpowiedzią była możliwość wypisywania recept na niektóre leki (ryc. 3).

\section{Opinie położnych na temat ich zawodu}

Analizie poddano opinie 115 położnych na temat ich sytuacji zawodowej. W badaniu ankietowym najliczniejsze grupy stanowiły położne w wieku $35-45$ oraz 45-55 lat. Grupy te liczyły odpowiednio $52(45,22 \%)$ osoby oraz $36(31,3 \%)$ osób. Co dziesiąta położna biorąca udział w badaniu ankietowym miała 25-35 lat (13 osób, 11,3\%). Najmniej liczne okazały się grupy najmłodszych i najstarszych położnych. Liczyły odpowiednio $9(7,83 \%)$ oraz $5(4,35 \%)$ osób. Większość położnych, które wypełniły kwestionariusze, ukończyła policealną lub pomaturalną szkołę położnych (67 osób, 58,26\% ogółu). Co piąta ankietowana miała wykształcenie wyższe pierwszego stopnia na kierunku położnictwo (23 osoby, 20\%). Tytuł magistra położnictwa lub pielęgniarstwa posiadało 13 badanych położnych (11,3\%), natomiast studia magisterskie na innym kierunku ukończyło $12(10,43 \%)$ respondentek. Najwięcej położnych objętych analizą przepracowało w zawodzie 5-15 lub $>25$ lat. Grupy te liczyły po 34 osoby i stanowiły $29,57 \%$ ogółu ankietowanych. Nieco mniej licznie reprezentowane były położne ze stażem pracy $15-25$ lat (32 osoby, $27,83 \%$ ). W badaniu ankietowym wzięło również udział 15 (13,04\%) najmłodszych stażem położnych.

Większość ankietowanych położnych - bez względu na staż pracy - uważała, że zawód, który wykonuje, jest ustawowo samodzielny. Opinię taką wyraziło łącznie 84 badanych, czyli 73,04\% ogółu. Ze względu na zbyt małą liczebność grupy położnych pracujących krócej niż 5 lat (zaledwie 15 osób) nie było możliwe wyznaczenie wskaźników struktury udzielanych odpowiedzi. 
W jednym z pytań kwestionariusza poproszono położne, aby wskazały czynności, które położna może wykonywać samodzielnie - bez zlecenia lekarskiego. Prawidłowa odpowiedź na powyższe pytanie polegała na zaznaczeniu wszystkich wymienionych czynności. W przypadku niewskazania choćby jednej z nich odpowiedź uznano za błędną. Wyraźna większość badanych położnych z każdej grupy stażowej nie potrafiła prawidłowo wskazać czynności, które może wykonywać samodzielnie - bez zlecenia lekarza - w ramach indywidualnej lub grupowej praktyki. Błędnych odpowiedzi na powyższe pytanie udzieliło łącznie 75 ankietowanych, co stanowiło $65,22 \%$. Największy odsetek prawidłowych odpowiedzi odnotowano wśród położnych najstarszych stażem (14 osób, 41,18\% grupy). Odpowiedzi błędne natomiast najczęściej pojawiały się wśród osób wykonujących zawód położnej 15-25 lat (23 osoby, 71,88\%).

Ponad połowa położnych wykonujących swój zawód 5-15 lat nie zawsze mogła w aktualnym miejscu pracy wykorzystywać swoje kompetencje zawodowe w dużym zakresie (18 osób, 52,94\% grupy). Była to najczęściej wskazywana odpowiedź również przez ankietowane ze stażem pracy przekraczającym 25 lat (15 osób, 44,12\%). W grupie położnych pracujących w zawodzie 15-25 lat pojawiały się zazwyczaj opinie, że w aktualnym miejscu pracy istniała możliwość wykorzystywania przez nie swoich kompetencji zawodowych w dużym zakresie (14 osób, 43,75\%). Zaobserwowane zależności nie okazały się jednak istotne statystycznie $(\mathrm{p}>0,05)$ - tabela 11 .

T a b e l a 11. Wyniki testu niezależności między stażem pracy położnych a możliwością wykorzystywania własnych kompetencji zawodowych w miejscu pracy

Statystyki:

\begin{tabular}{lccc}
\multirow{2}{*}{ Parametry } & \multicolumn{4}{c}{ Statystyki: } \\
\cline { 2 - 4 } & $\chi^{2}$ & $\mathrm{df}$ & $\mathrm{p}$ \\
\hline$\chi^{2}$ Pearsona & 8,963901 & 6 & 0,17563 \\
\hline$\chi^{2} \mathrm{NW}$ & 8,764994 & 6 & 0,18724 \\
\hline
\end{tabular}

Zdecydowana większość ankietowanych - bez względu na staż pracy - uważała, że należałoby poszerzyć obecny zakres kompetencji zawodowych położnych. Opinia ta pojawiała się najczęściej wśród położnych pracujących 15-25 lat (25 osób, 83,33\%). Najrzadziej twierdziły tak respondentki o stażu pracy nie dłuższym niż 5 lat (10 osób z 15).

Większość ankietowanych (73 osoby, 63,48\%) uważała, że kompetencje położnych należałoby poszerzyć o możliwość wystawiania recept na większą liczbę leków (ryc. 4). Najrzadziej w tym kontekście wskazywano też orzekanie o niezdolności do pracy (33 osoby, 28,7\%).

Położne zapytano o największe ich zdaniem trudności w samodzielnym praktykowaniu. Odpowiedzi udzielone przez respondentki przedstawiono na rycinie 5 .

\section{Wiedza lekarzy i pielęgniarek na temat zawodu położnej}

Większość lekarzy biorących udział w badaniu ankietowym to kobiety. Grupa ta liczyła 30 osób i stanowiła $75 \%$ ogółu. Co czwarty lekarz poddany analizie był mężczyzną

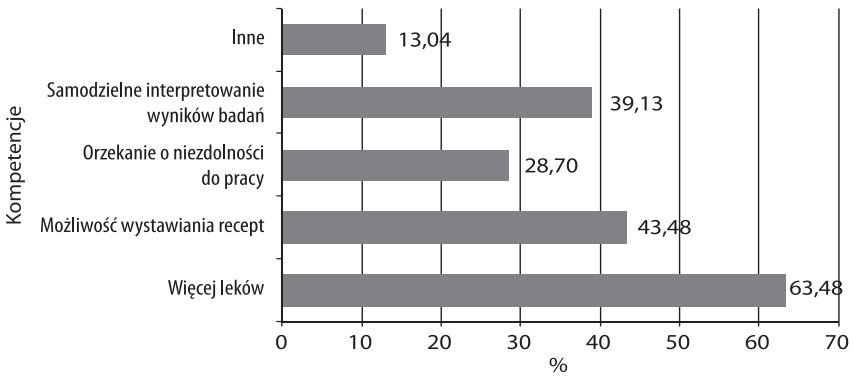

Ryc. 4. Zakres, o jaki należałoby poszerzyć kompetencje położnych

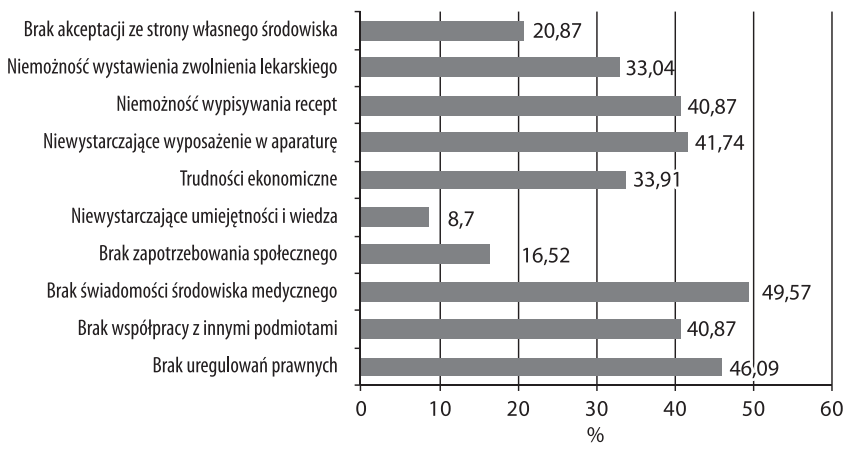

Ryc. 5. Największe trudności w samodzielnym praktykowaniu położnych w opinii badanych

(10 osób, $25 \%$ ). Niemal wszystkie pielęgniarki były kobietami (98 osób, 98\%). Kwestionariusze wypełniło zaledwie 2 pielęgniarzy ( $2 \%)$.

Ze względu na proces edukacyjny w Polsce w badaniu ankietowym nie wziął udziału ani jeden lekarz $<25$. r.ż. W tak młodym wieku była natomiast co dziesiąta ankietowana pielęgniarka (11 osób, 11\%). Lekarze objęci analizą mieli zazwyczaj 45-55 lat (15 osób, 37,5\%), natomiast wśród pielęgniarek najliczniejszą grupę stanowiły osoby w wieku 35-45 lat (39 osób, 39\%). Kwestionariusze wypełniło również $5(12,5 \%)$ lekarzy oraz $3(3,03 \%)$ pielęgniarki > 55. r.ż. Strukturę ankietowanych ze względu na staż pracy przedstawiono na rycinie 6 .

Większość lekarzy biorących udział w badaniu mieszkała w Szczecinie, natomiast ponad połowa pielęgniarek, które wypełniły kwestionariusze, wskazała jako miejsce zamieszkania inną miejscowość (odpowiednio: 27 osób, $69,23 \%$ oraz 55 osób, $55 \%$ ).

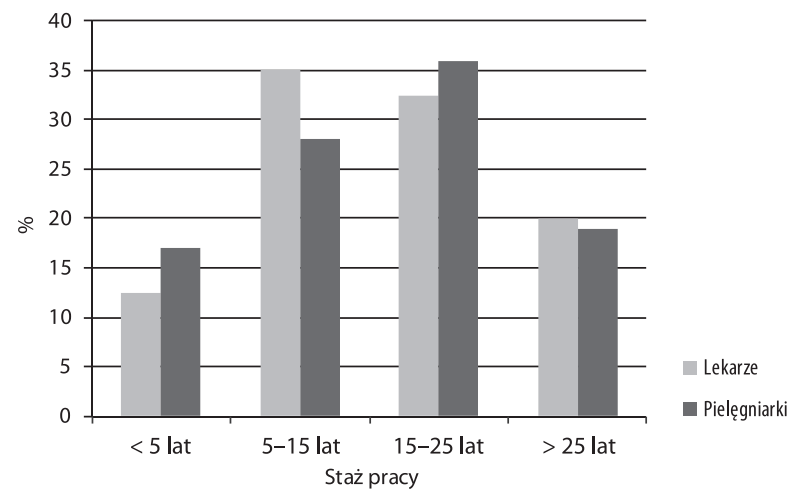

Ryc. 6. Podział ankietowanych lekarzy i pielęgniarek ze względu na staż pracy 
Grupom zawodowym pielęgniarek i lekarzy zadano pytanie dotyczące samodzielnego charakteru zawodu. Opis tego, czy położne posiadają określony zakres samodzielności zawodowej, przedstawiono w tabeli 12 .

Pielęgniarki wyraźnie częściej od lekarzy uważały, że położne posiadają pewien zakres samodzielności zawodowej (odpowiednio: 57 osób, 57\% oraz 15 osób, 37,5\%), natomiast lekarze częściej od pielęgniarek wskazywali wariant odpowiedzi „nie wiem” (odpowiednio: 16 osób, $40 \%$ oraz 17 osób, 17\%). Zaobserwowana zależność miała charakter istotny statystycznie $(\mathrm{p}<0,05)$ - tabela 13 .

\section{T a b e 1 a 12 . Wiedza lekarzy i pielęgniarek na temat samodzielności zawodowej położnych}

\begin{tabular}{lccc}
$\begin{array}{c}\text { Samodzielność } \\
\text { zawodowa } \\
\text { położnych }\end{array}$ & Lekarze & Pielęgniarki & Razem \\
\hline Tak & $15(37,50 \%)$ & $57(57,00 \%)$ & $72(51,43 \%)$ \\
\hline Nie & $9(22,50 \%)$ & $26(26,00 \%)$ & $35(25,00 \%)$ \\
\hline Nie wiem & $16(40,00 \%)$ & $17(17,00 \%)$ & $33(23,57 \%)$ \\
\hline Ogół & $40(100,00 \%)$ & 100 & 140 \\
\hline
\end{tabular}

T a b e l a 13. Wyniki testu niezależności wiedzy lekarzy i pielęgniarek na temat samodzielności zawodowej położnych Statystyki:

\begin{tabular}{lccc}
\multirow{2}{*}{ Parametry } & \multicolumn{3}{c}{ Statystyki: } \\
& \multicolumn{2}{c}{ samodzielność zawodowa (3) } & zawód (2) \\
\cline { 2 - 4 } & $\chi^{2}$ & $\mathrm{df}$ & $\mathrm{p}$ \\
\hline$\chi^{2}$ Pearsona & 8,664621 & 2 & 0,01314 \\
\hline$\chi^{2} \mathrm{NW}$ & 8,204206 & 2 & 0,01654 \\
\hline
\end{tabular}

Ponad połowa badanych lekarzy i pielęgniarek ze stażem pracy 5 lat oraz 5-15 lat uważała, że położna może bez zlecenia lekarskiego podać leki ważne dla przebiegu porodu, połogu i laktacji (odpowiednio: 12 z 22 osób oraz 26 respondentów, $61,9 \%$ grupy). Blisko połowa badanych wykonujących zawód medyczny 15-25 lat również podzielała tę opinię (24 osób, 48,89\%). Natomiast wśród ankietowanych ze stażem pracy przekraczającym 25 lat przeważał pogląd, że położna może podać jedynie niektóre z leków wymienionych w pytaniu (11 osób z 27). Wyniki testu $\chi^{2}$ nie potwierdzają jednak, by zaobserwowana zależność była statystycznie istotna $(p>0,05)$. Można zatem stwierdzić, że bez względu na staż pracy lekarze i pielęgniarki odpowiadali na powyższe pytanie podobnie - zazwyczaj uznawali, że położna mogła bez zlecenia lekarskiego podać leki ważne dla przebiegu porodu, połogu oraz laktacji.

Przeprowadzono również analizę porównawczą opinii obu grup zawodowych dotyczących uprawnień położnych do wykonywania poszczególnych czynności. Wyniki przedstawiono w tabeli 14.

W tabeli 15 zamieszczono ogólne opinie lekarzy i pielęgniarek na temat zawodu. W przypadku każdego z wymienionych elementów ocena zawodu położnej przez lekarzy różniła się od opinii pielęgniarek (wszystkie $\mathrm{p}<0,05$ ). Z kolei lekarze istotnie częściej uważali, że aktualne kompetencje zawodowe położnych są wystarczające ( $45 \%$ lekarzy w stosunku do $23 \%$ pielęgniarek).

Ważnym problemem dla grupy zawodowej położnych jest możliwość wykorzystywania swoich kompetencji w praktyce. Zapytano środowisko lekarzy oraz pielęgniarek

T a b e 1 a 14. Wiedza lekarzy i pielęgniarek na temat dzialań, do których polożne mają prawo

\begin{tabular}{|c|c|c|c|}
\hline Wyszczególnienie & Lekarze & Pielęgniarki & $\mathrm{p}$ \\
\hline Wystawianie skierowań do specjalistów & $13(32,50 \%)$ & $40(40,00 \%)$ & 0,2050 \\
\hline Prowadzenie poradnictwa w zakresie żywienia noworodków & $34(85,00 \%)$ & $91(91,00 \%)$ & 0,1508 \\
\hline Kierowanie na badania diagnostyczne & $22(55,00 \%)$ & $59(59,00 \%)$ & 0,3328 \\
\hline Wykonywanie badania fizykalnego & $28(70,00 \%)$ & $91(91,00 \%)$ & 0,0010 \\
\hline Wykonywanie i interpretacja badania położniczego zewnętrznego & $31(77,50 \%)$ & $88(88,00 \%)$ & 0,0591 \\
\hline Wykonywanie i interpretacja badania położniczego wewnętrznego & $17(42,50 \%)$ & $47(47,00 \%)$ & 0,3150 \\
\hline Wykonywanie i interpretacja kardiotokografii & $22(55,00 \%)$ & $74(74,00 \%)$ & 0,0152 \\
\hline Nacięcie, znieczulenie miejscowe i szycie krocza & $17(42,50 \%)$ & $53(53,00 \%)$ & 0,1318 \\
\hline Szycie krocza pękniętego I stopnia & $20(50,00 \%)$ & $51(51,00 \%)$ & 0,4575 \\
\hline Zdjęcie szwów z krocza & $32(80,00 \%)$ & $94(94,00 \%)$ & 0,0069 \\
\hline Udzielanie pomocy ręcznej w porodach miednicowych & $21(52,50 \%)$ & $71(71,00 \%)$ & 0,0195 \\
\hline Zlecanie transportu chorego & $12(30,00 \%)$ & $43(43,00 \%)$ & 0,0785 \\
\hline
\end{tabular}

T a b e 1 a 15. Ogólne opinie lekarzy i pielęgniarek na temat zawodu położnej

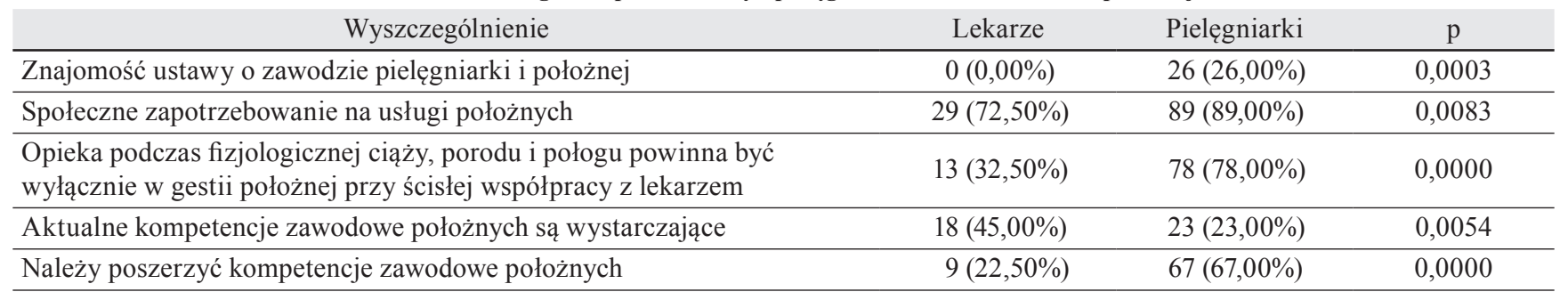


z województwa zachodniopomorskiego o przyczyny niepełnej samodzielności w zawodzie położnej. Opinie ankietowanych na ten temat umieszczono w tabeli 16.

Samodzielność zawodowa nierozłącznie wiąże się z odpowiedzialnością za podejmowane działania. Zapytano respondentów o to, kto ponosi odpowiedzialność za pracę położnych w placówkach ochrony zdrowia. Wyniki przedstawiono w tabeli 17.

T a b e 1 a 16. Przyczyny niesamodzielności położnych w opinii lekarzy i pielegniarek

\begin{tabular}{lccc}
\multicolumn{1}{c}{ Powód } & Lekarze & Pielęgniarki & p \\
\hline Kodeks pracy & $10(25,00 \%)$ & $38(38,00 \%)$ & 0,0727 \\
\hline Ustawy zawodowe & $17(42,50 \%)$ & $27(27,00 \%)$ & 0,0383 \\
\hline $\begin{array}{l}\text { Postrzeganie zawodu jako } \\
\text { niesamodzielnego }\end{array}$ & $5(12,50 \%)$ & $39(39,00 \%)$ & 0,0014 \\
\hline Wewnętrzne zarządzenia & $15(37,50 \%)$ & $39(39,00 \%)$ & 0,4347 \\
\hline Nie wiem & $11(27,50 \%)$ & $13(13,00 \%)$ & 0,0208 \\
\hline Inne & $0(0,00 \%)$ & $2(2,00 \%)$ & 0,1846 \\
\hline
\end{tabular}

T a b e 1 a 17. Osoby odpowiedzialne za dzialania zawodowe położnych pracujących w placówkach ochrony zdrowia w opinii lekarzy i pielęgniarek

Osoba odpowiedzialna Lekarze Pielęgniarki p

\begin{tabular}{llll}
\hline Położna & $27(67,50 \%)$ & $75(75,00 \%)$ & 0,1844
\end{tabular}

\begin{tabular}{llll}
\hline Lekarz dyżurny & $11(27,50 \%)$ & $20(20,00 \%)$ & 0,1680 \\
\hline
\end{tabular}

\begin{tabular}{llll}
\hline Dyrektor & $7(17,50 \%)$ & $13(13,00 \%)$ & 0,2465 \\
\hline
\end{tabular}

\begin{tabular}{llll}
\hline Ordynator & $11(27,50 \%)$ & $23(23,00 \%)$ & 0,2879
\end{tabular}

\begin{tabular}{llll}
\hline Pielęgniarka naczelna & $2(5,00 \%)$ & $11(11,00 \%)$ & 0,1355 \\
\hline
\end{tabular}

\begin{tabular}{llll}
\hline Oddziałowa & $12(30,00 \%)$ & $21(21,00 \%)$ & 0,1295
\end{tabular}

Wspólna odpowiedzialność $\quad 8(20,00 \%) \quad 8(8,00 \%) \quad 0,0229$

Lekarze znacznie częściej niż pielęgniarki uważali, że za działania zawodowe położnych pracujących w placówce ochrony zdrowia obowiązuje wspólna odpowiedzialność (po 8 osób, odpowiednio: $20 \%$ oraz $8 \%$, p $<0,05$ ). Nie było podstaw do odrzucenia hipotez stwierdzających jednakowe udziały pielęgniarek oraz lekarzy wskazujących poszczególne osoby odpowiedzialne za działania położnych pracujących w placówce medycznej (pozostałe p > 0,05).

\section{Dyskusja}

Na przestrzeni wieków zmianom ulegały różne uwarunkowania praktykowania zawodu położnej. Dzisiejsze ramy tej profesji na obszarze Unii Europejskiej - również na obszarze naszego kraju - wyznaczają kierunki działania przedstawicieli tego zawodu. Dawne akty prawne dotyczące zawodu położnej zaliczały ją do personelu pomocniczego. Praca położnej polegała więc na wykonywaniu przede wszystkim zleceń lekarskich [10]. Świątek w swoim artykule przypomina instrukcję ministra zdrowia z 1958 r., w której to na przykład podanie przez pielęgniarkę samodzielnie leku przeciwbólowego lub zmiana opatrunku były traktowane jako przekroczenie kompetencji i nielegalne wykonywanie zawodu lekarza [11]. Nesterowicz uważa, że w toku prac kodyfikacyjnych nad zawodem pielęgniarki i położnej środowiska lekarskie kwestionowały niezależność tych zawodów [10]. Jednakże ustawodawca uznał oba za samodzielne, co w efekcie dało ramy autonomicznych kompetencji pielęgniarek i położnych [12]. Karkowska zauważa, że prawodawca tylko w stosunku do zawodów pielęgniarki i położnej przyjął bezpośrednią formułę, nazywając te zawody samodzielnymi zawodami medycznymi [13]. Zdaniem autorki nie było takiej potrzeby przy określaniu autonomii zawodów lekarza i lekarza dentysty, gdyż oba posiadają swoją kliniczną niezależność wobec innym profesji medycznych. Konieczność uchwalenia ustawy wychodzącej naprzeciw zmianom w zawodzie pielęgniarki i położnej Nesterowicz upatruje w fakcie znacznego usamodzielnienia się zawodu, rozszerzenia obowiązków i uprawnień pielęgniarek i położnych, lepszego wykształcenia oraz systemowych przekształceń w służbie zdrowia wpływających na formy wykonywania tych zawodów [10]. Rutka interpretuje więź zawodową lekarza i położnej nie jako podporządkowanie, ale jako więź merytoryczną, partnerską [14]. Na podstawie obowiązujących aktów prawnych dotyczących zawodu położnej w Polsce można przyjąć, że kompetencje zawodowe przedstawicieli tej profesji są szerokie. Bączek zauważa, że wszechstronne kompetencje wiążą się z umiejętnością samodzielnego działania podjętego na podstawie wykształcenia oraz posiadanej wiedzy. Zdaniem Baczek samodzielne kompetencje powinny być realizowane na czterech obszarach życia zawodowego położnej: myślenia, działania, podejmowania decyzji i uczenia się [15]. Jeżeli jest mowa o samodzielności oraz autonomii zawodu, powinno być także oczywistym, że nie ma takiej profesji, która mogłaby kontrolować dany zawód lub z nim konkurować. Tego zdania w stosunku do zawodu pielęgniarki i położnej jest też Piórkowska [16]. W literaturze tematu nie znaleziono badań dotyczących samodzielności zawodu położnej, do których można byłoby się odnieść.

Wśród licznych samodzielnych kompetencji polska położna może m.in. autonomicznie opiekować się kobietą podczas fizjologicznej ciąży, porodu i połogu. Śliwiń$s k a$ w artykule na temat zadań położnej również odnosi się do możliwości prawnej, jaką jest opieka sprawowana przez położną nad zdrową ciężarną w okresie okołoporodowym [17]. Autorka zauważa też, że kompetencje do samodzielnego prowadzenia przez położną ciąży, porodu i połogu o fizjologicznym przebiegu przypisane na mocy ustawy [18], nakładają się z identycznymi kompetencjami funkcjonującymi dla zawodu lekarza. Tego samego zdania jest Świątek [11]. Janiuk [19] zauważa, że domeną polskiej położnej jest fizjologia, edukacja i profilaktyka. Zachęca więc położne do działań w tych obszarach. Watson $i$ wsp. przeprowadzili w 2002 r. w Australii badania wśród położnych dotyczące poszerzenia ich kompetencji o interpretacje wyników badań i związane z tym inicjowanie leczenia [20]. Badacze doszli do wniosku, że poszerzenie roli położnej w zakresie interpretacji wyników badań i samodzielnego podawania 
leków będzie korzystne dla poziomu opieki zdrowotnej, jak również pozwoli na zaspokojenie oczekiwań pacjentów, z jednoczesnym obniżeniem kosztów opieki. Innym pozytywnym rezultatem zdaniem Watson $i$ wsp. powinien być wzrost satysfakcji położnych z wykonywanej pracy oraz wzmocnienie autonomii profesji i odpowiedzialności położnych w miejscu pracy [20]. Zacytowane wyniki badań są podobne do przedstawionych w pracy własnej. Zarówno położne, jak i odbiorczynie ich usług w Polsce oczekują poszerzenia kompetencji położnych z nadzieją na obopólną szeroko pojętą satysfakcję.

Emancypacja zawodu położnej i pielęgniarki jest procesem, który trwa od wielu lat [21]. Transformacja ta odbywa się na kilku płaszczyznach funkcjonowania położnych, m.in. na płaszczyźnie relacji z innymi profesjonalistami medycznymi oraz na płaszczyźnie własnej grupy zawodowej. Problemem w samodzielnym praktykowaniu - zdaniem ankietowanych - jest nieznajomość przez środowisko medyczne m.in. samodzielnych kompetencji położnych (49,57\%). Baczek opisuje problem ograniczonych możliwości realizacji zadań zawodowych przez położne w Polsce, wskazując na uwarunkowania społeczno-kulturowe i ekonomiczne [4]. Natomiast Jędrzejewska dostrzega trudności, takie jak walka o ustawową samodzielność zawodową $\mathrm{z}$ innymi świadczeniodawcami, czy niskie zarobki [22]. Jędrzejewska zwraca uwagę, że podobne dylematy miały położne z innych państw europejskich [22]. Jednak problemy te zostały pokonane. Stało się to dzięki determinacji, konsekwencji i profesjonalizmowi położnych. Kołtunowicz i Baczek w prowadzonych badaniach wśród 72 czynnych zawodowo położnych z Warszawy uzyskali wyniki podobne do tych z pracy własnej [23]. Ponad połowa respondentów biorących udział w badaniach Kottunowicz i Baczek przyznawała, że ma problemy w egzekwowaniu ustawowej samodzielności. Położne pracujące w Warszawie uważały, że problemy z zakresu samodzielności zawodowej wynikają z odgórnych przepisów, braku współpracy z lekarzami, a także braku podstawowego sprzętu.

Ankietowanym lekarzom i pielęgniarkom zadano również pytanie o to, czy wiedzą, kto ponosi odpowiedzialność za poczynania zawodowe położnej zatrudnionej w placówce ochrony zdrowia. Lekarze istotnie statystycznie częściej wskazywali na wspólną odpowiedzialność członków zespołu terapeutycznego w stosunku do badanych pielęgniarek $(\mathrm{p}<0,05)$. W piśmiennictwie nie znaleziono wyników badań, do których można by się odnieść.

Aby skorzystać z określonej usługi, powinna być ona dla odbiorcy wartością, a przede wszystkim potencjalny nabywca musi mieć świadomość, że określone świadczenie istnieje oraz wiedzieć, kto je oferuje. Respondentki uważały, że istnieje zapotrzebowanie na usługi położnej. Kobietom zadano pytanie, czy gdyby istniała taka możliwość, wybrałyby położną do prowadzenia porodu. W pytaniu tym chodziło o położną, która niekoniecznie byłaby pracownikiem sali porodowej w danym szpitalu. Zdecydowana większość badanych odpowiedziała twierdząco (81,63\%). Gierszewska $i$ wsp. w badaniach przeprowadzonych w 2003 r. wśród kobiet rodzących w Szpitalu Wojewódzkim im. dr. J. Biziela w Bydgoszczy pytali o oczekiwania kobiet rodzących wobec położnych [24]. Jednym z wyników tych badań było oczekiwanie obecności odpowiedzialnej i życzliwej położnej.

Przedstawione wyniki badań, ich omówienie oraz próba dyskusji wskazują na potrzebę edukacji wszystkich grup zawodowych z zakresu kompetencji zawodowych położnych w dziedzinie opieki nad matką i dzieckiem, nie wyłączając samych położnych. Wydaje się również zasadnym po przeanalizowaniu wyników badań - dotarcie do szeroko pojętego kręgu odbiorców usług położnych, czyli do kobiet i ich rodzin. Wnikliwszemu przyjrzeniu się i - być może zmianom powinno też ulec prawo medyczne, dzięki któremu należałoby stworzyć szerszą przestrzeń dla zawodu położnej, a tym samym przyczynić się do zaspokojenia oczekiwań kobiet będących w okresie okołoporodowym.

\section{Wnioski}

1. Korzystnym rozwiązaniem wydaje się stworzenie programów edukacyjnych skierowanych do pracowników ochrony zdrowia o ustawowych kompetencjach położnych, jak również szkolenie z zakresu samodzielnych kompetencji położnych w uczelniach medycznych w trakcie nauczania przed-i podyplomowego.

2. Zrewidowaniu powinny ulec funkcjonujące ustawy regulujące zawód położnych oraz inne, mające wpływ na ich pracę tak, aby umożliwić kobietom korzystanie $\mathrm{z}$ form opieki będących aktualnie poza ich zasięgiem.

3. Wydaje się zasadnym zintensyfikowanie promocji zawodu położnej przez samorząd zawodowy na szczeblu centralnym i lokalnym w celu dotarcia do szerokich rzesz przyszłych pacjentek/klientek z informacją o możliwych świadczeniach tej grupy zawodowej.

\section{Piśmiennictwo}

1. Brucker M:: The birth of midwifery. http://www3.utsouthwestern.edu/ midwifery/mdwfhistory.html (26.11.2004).

2. Women in scripture: a dictionary of named and unnamed women in the Hebrew Bible, the Apocryphal/Deuterocanonical books, and the New Testament. Eds: C. Meyers, T. Craven, R.S. Kraemer. Eedermans Publishing Co., Cambridge 2001, 592.

3. Komunikowanie interpersonalne w pielęgniarstwie. Eds: A. Kwiatkowska, E. Krajewska-Kułak, W. Panek. Wyd. Czelej, Lublin 2003, 289.

4. Bączek G.: Profesjonalizm a historia. Profesjonalna Położna. 2004, 1, 5-4.

5. Kitzinger S.: The politics of birth. Elsevier Butterworth-Heinemann, Edinburgh 2005, 235.

6. Drużdzel M., Dmoch-Gajzlerska E., Doroszewska. A.: Samodzielność i odpowiedzialność zawodowa w opinii współczesnej położnej na podstawie badań własnych. Położ Nauka Prakt. 2007, 1, 28-31.

7. Wybrane zagadnienia z pielęgniarstwa europejskiego. Eds: I. Wrońska, E. Krajeńska-Kułak. Wyd. Czelej, Lublin 2007, 214.

8. Nowak G.M.: Idzie nowe-uznanie trzech epok w położnictwie. Klin Perinatol Ginekol. 1996, 10, 293-298. 
9. Nowak G.: Trudna droga przemian. Konferencja „Potrzeby kobiet potrzeby nowoczesnego położnictwa”. Warszawa 1997.

10. Nesterowicz M.: Charakter prawny wykonywania zawodu pielęgniarki i odpowiedzialność cywilna za wyrządzone przez nią szkody. Prawo Med. 2003, 5, 117-126.

11. Świątek B.: Lekarz i pielęgniarka - ich wzajemne relacje w świetle obowiązujących przepisów. Przew Lek. 2000, 5, 16-17.

12. Rozporządzenie Ministra Zdrowia i Opieki Społecznej z dnia 19 stycznia 1993 r. w sprawie postępowania w przedmiocie odpowiedzialności zawodowej pielęgniarek i położnych. Dz.U. 1993, nr 9, poz. 45. http://isap.sejm.gov.pl/DetailsServlet?id=WDU19930090045 (6.11.2014).

13. Karkowska D.: Status zawodowy położnej - zarys problemu. Fundacja Rodzić po Ludzku, Warszawa 2007, 26.

14. Rutka R.: Organizacja Zakładu Opieki Zdrowotnej. In: Nowoczesne zarządzanie zakładem opieki zdrowotnej. Eds: B. Nogalski, J.M. Rybicki. Dom Organizatora, Toruń 2002, 29-60.

15. Bączek G.: Położna - zawód samodzielny. Położ Nauka Prakt. 2007, $1,24-27$.
16. Piórkowska M.: Pielęgniarstwo - rzemiosło czy profesja? Mag Pielęg Położ. 1998, 5, 6-7.

17. Śliwińska M.: Położne świadome profesjonalnych zadań. Mag Pielęg Położ. 2005, 1-49.

18. Obwieszczenie Marszałka Sejmu Rzeczpospolitej Polskiej z dnia 29 sierpnia 2009 r. w sprawie ogłoszenia jednolitego tekstu ustawy o zawodach pielęgniarki i położnej. Dz.U. 2009, nr 151, poz. 1217. http:// isap.sejm.gov.pl/DetailsServlet?id=WDU20091511217 (25.10.2014).

19. Janiuk E.: Pole do popisu dla położnych. Mag Pielęg Położ. 2006, 5, 35.

20. Watson J., Turnbull B., Mills A.: Evaluation of the extended role of the midwife: the voices of midwives. Int J Nurs Pract. 2002, 8, 257-264.

21. Hamer H.: Rozwój przez wprowadzanie zmian. Centrum Edukacji Medycyny, Warszawa 1998, 277.

22. Jędrzejewska L.: Samodzielność położnych. Mag Pielęg Położ. 2006, 6, 35.

23. Koltunowicz M., Bączek G.: Samodzielność położnych. Mag Pielęg Położ. 2005, 5, 36 .

24. Gierszewska M., Klusek D., Lewandowska J.: Oczekiwania kobiet rodzących wobec położnych pracujących na sali porodowej. Pielęg Pol. 2003, 2 (16), 119-123. 